\title{
Imprinting Gene
}

National Cancer Institute

\section{Source}

National Cancer Institute. Imprinting Gene. NCI Thesaurus. Code C54401.

A gene that does not exhibit equal expression of both alleles due to repression or inactivation, resulting in the genetic non-equivalence of mammalian paternal and maternal genomes. 